\title{
Lumen
}

Selected Proceedings from the Canadian Society for Eighteenth-Century Studies

\section{Joseph Priestley's Time Charts: The Use and Teaching of History by Rational Dissent in late Eighteenth-Century England}

\section{Arthur Sheps}

Volume 18, 1999

Representations of Time in the XVIIIth Century

Le temps et ses représentations au dix-huitième siècle

URI : https://id.erudit.org/iderudit/1012372ar

DOI : https://doi.org/10.7202/1012372ar

Aller au sommaire du numéro

Éditeur(s)

Canadian Society for Eighteenth-Century Studies / Société canadienne d'étude du dix-huitième siècle

ISSN

1209-3696 (imprimé)

1927-8284 (numérique)

Découvrir la revue

Citer cet article

Sheps, A. (1999). Joseph Priestley's Time Charts: The Use and Teaching of History by Rational Dissent in late Eighteenth-Century England. Lumen, 18, 135-154. https://doi.org/10.7202/1012372ar

Copyright (c) Canadian Society for Eighteenth-Century Studies / Société canadienne d'étude du dix-huitième siècle, 1999
Ce document est protégé par la loi sur le droit d'auteur. L'utilisation des services d'Érudit (y compris la reproduction) est assujettie à sa politique d'utilisation que vous pouvez consulter en ligne.

https://apropos.erudit.org/fr/usagers/politique-dutilisation/ 


\section{Joseph Priestley's Time Charts: The Use and Teaching of History by Rational Dissent in late Eighteenth-Century England}

The fame of Joseph Priestley (1733-1804) rests today chiefly on his career as an experimental scientist and as a polemicist in defence of Protestant dissent and Rational Religion. He thought of himself, however, primarily as a minister of religion and as an educator. In these occupations, and indeed in all of his endeavours, the teaching and study of history played a critical role. Works about history such as the Charts of Biography and History (1765 and 1769), and the Syllabus of Lectures on History and General Policy (1765) were among his earliest publications. His first scientific publications, The History and Present State of Electricity (1767) and The History and Present State of Discoveries relating to Vision, Light and Colours (1772), were as an educator and historian of science. Throughout his life he was to use the history of the early Christian church polemically in defence of his theological views. His last published writings, the volumes which make up A General History of the Christian Church from the Fall of the Western Empire until the Present Time (1802-03), were also historical.

The Lectures on History and the Charts of Biography and History were not notable as original works of historical scholarship or narrative. Rather, as we shall see, they were important as pedagogical tools and as discussion, or statements, about the teaching, purpose and use of history, especially for the religious and cultural communities which Priestley inhabited in late eighteenth-century England.

Priestley taught at Warrington Academy, in Yorkshire, from 1761 to 1767. Warrington was one of the great centres of higher education for Protestant Dissenters who were denied access to degrees at the ancient universities in England. ${ }^{1}$ These academies trained prospective ministers for Dissenting congregations. Perhaps more importantly, the sons of the prosperous Dissenting laity - young men destined for careers in commerce and manufacturing - received their higher education at them. ${ }^{2}$ 
Priestley had originally been engaged as a tutor in modern languages although he said that at the time his preferred interests were mathematics and natural philosophy, that is science. Shortly after his arrival at Warrington he came to the conclusion that the curriculum which he found in place there had some serious deficiencies. To rectify these he introduced three new courses, all historical, dealing with the Constitution and Laws of England, politics, and what he called general (that is, public) policy. In 1765 he published a synopsis of the lectures in these courses, both separately and as a part of his Essay on a Course of Liberal Education for Civil and Active Life in which he outlined his pedagogical principles. The structure and heart of the new courses was, he explained, the study of Civil History in order that the students would better understand law, government, manufactures, commerce, and the real roots of naval and military force and conflict. ${ }^{3}$

The curriculum at Warrington, before Priestley's reforms, was still in many ways similar to that at the ancient universities. ${ }^{4}$ It focused on classical literary subjects and on philosophy, mathematics and logic. This was thought to be appropriate as a preparation for the clergy and for the learned professions. Priestley argued that such an education was illsuited for many of the young men he was teaching, the sons of the commercial middle classes who were educated at the Dissenting academies. The traditional curriculum at Warrington did not prepare them for the kind of active life in commerce for which they were destined.

Priestley did not limit his criticism to the Dissenting academies. In the Essay on [...] Education he pointed out that the public schools and universities also did not properly educate those who attended them. The great in rank, fortune and influence who were educated at the universities and who were inevitably going to be the leaders of civil life did not learn what the sources of wealth, power and happiness were. Nor did those educated at the universities who went into the liberal professions of law, arms, divinity or medicine, 'gentlemen of large property who have themselves the greatest interest in the fate of their country.' Neither the future leaders of commerce, at the Dissenting academies, nor the governing and professional classes being trained at the public schools and universities, were receiving the education which would equip them properly for a civil and active life. ${ }^{5}$

There was a time, he wrote, when people with purely scholarly interests might have been able to 'disclaim all pretensions to any branch of knowledge but what was taught in the universities.' Now, however, the scholarly and the rest of the world were in more familiar intercourse, and the public good required knowledge of the sources of wealth. The learned are 'obliged to converse upon the same topics' as those in civil and active life. 'The subjects of modern history, policy, arts, manufac- 
tures, commerce, \&c, are the general topics of all sensible conversation'. What Priestley was arguing was that a knowledge of modern history the subject of his new courses - was both 'pleasing and interesting' for the scholarly and the learned and necessary for all those in public life. It could no longer be disputed, he wrote, that 'an acquaintance with the subjects of these lectures is calculated to form the statesman, the military commander, the lawyer, the merchant, and the accomplished country gentleman.' His purpose, he said in explaining his ideas on education, was not only to make history intelligible to persons who may choose to read it for their amusement, but, more importantly, 'to facilitate its subserviency to the highest uses to which it can be applied; to contribute to forming the able statesman and the useful and intelligent citizen. ${ }^{\prime}$

If the studies he recommended in his Syllabus were to be introduced into all places of liberal education, Priestley argued, there would be a general increase in public happiness and the reduction of many of the ills and evils under which the country laboured. He was careful to point out that he was advocating improvement and amelioration, the reform of evils, not radical social change. He disavowed any intention of encouraging these studies among 'low mechanics [...] and among persons with whom it could be of no service to their country, and often a real detriment to themselves.' Rather, the type of education that he was proposing would be valuable for the leaders of commerce. It would also increase real useful love for the good of the country among people of rank, such as ministers of state, military commanders, and members of Parliament, who would now thoroughly understand the interests of the country. The 'capital advantage we derive from [the study of] history', he claimed, 'is that from this source only can be derived all future improvements in the science of government. ${ }^{7}$

There was, however, another purpose for the study of history in addition to preparation for public life. What is not often appreciated is that the study of history, for Priestley, was prized as branch of divinity which increases our knowledge of God as manifested in the world and demonstrates God's providential care for mankind.

Priestley was a materialist and a determinist. These views often led to the accusation of heresy or even atheism, but Priestley coupled them firmly to a belief in immortality and revealed religion and to a kind of theistic cosmic optimism. Science, rational and historical investigation, and liberal reform, he thought, were the chief tools with which improvement and progress would inevitably be brought about. His efforts should not be seen, however, as a reflection of increasing secularization. He, himself, saw his work, and the study of history, as acts of devotion which would tend 'to strengthen the sentiments of virtue, by the variety of views in which it exhibits the conduct of Divine Providence, and 
points out the hand of God, in the affairs of men'. The relationship between Priestley's religious views and beliefs and many other aspects of his work has been carefully examined. It is not possible, however, to appreciate fully how Priestley reconciled his materialism with his religious views without considering his ideas about the meaning and uses of history. The importance, for Priestley, of the study of history as a religious act or as an aid to devotion and to an understanding of the will of Providence, must be considered. ${ }^{8}$

There had been intimations of materialism in Priestley's earliest work. His reading, in 1754, of Anthony Collins' A Philosophical Enquiry Concerning Human Liberty (1715) and David Hartley's Observations on Man (1749) were his first encounter with the idea of philosophical necessity. He became a 'necessarian' or determinist, but at the same time he insisted that the doctrine of philosophical necessity was a source of spiritual satisfaction and improved Christian piety. ${ }^{9}$

In the late 1750s he had argued against the possibility of miracles as sudden instruments of divine influence in God's orderly regulated universe. $^{10}$ A 1764 sermon, No Man Liveth to Himself, influenced by Hartley's physiological psychology, contains a kind of divinely-ordered sociobiology. In An Essay on the First Principles of Government (1768) Priestley exhibited more fully his cosmic and optimistic determinism coupling his 'belief in the doctrine of an overruling Providence' to the conviction that what appears to be noxious in the unfolding of history is, in fact, always 'subservient to the wise and gracious design' of the Divine will. That is, necessity was part of the divine order, but whatever is, is for the best, because a benevolent God has willed it. ${ }^{11}$

The philosophical and theological underpinnings of this reading of history were fully developed by Priestley in two works, both published in 1777, Disquisitions relating to Matter and Spirit and The Doctrine of Philosophical Necessity Illustrated. These works were the first clear-cut statement from someone claiming to be a Christian of the material homogeneity of human nature and the compatibility of materialism with revealed religion. He was 'of the firmest persuasion that man is wholly material'. Our being wholly material, however, did not preclude the active presence of a divine will, nor did it preclude immortality which was promised to us through the historical evidence of Christ's bodily resurrection. ${ }^{12}$

History, Priestley thought, is the working out of the natural laws of a material universe. Acceptance of this materialistic determinism did not lead to atheism; rather it encouraged true piety and belief. History shows us that the laws of the universe had been established by God to effect the divine goal, which is the greatest possible universal human happiness. We might be disconcerted by the appearance of evil and the darker 
shades of nature, but by reading history we shall learn to see that 'every thing that comes to pass [is] under the government of God; [...] that all evils lead to and terminate in the greater good' in the grand and necessary scheme of Creation. ${ }^{13}$

These notions about a manifest beneficent Divine Providence were spelled out in the Lectures on History and General Policy (1788) which Priestley first delivered, as part of his new courses at Warrington, in the early 1760s and in his Essay on the First Principles of Government (1768). In them Priestley revealed a belief in progress which followed from his cosmic optimism:

[h]ighly as we think of the wisdom of our ancestors we justly think of ourselves, of the present age, wiser and [...] must see that we can [...] improve upon institutions that have been transmitted to us. Let us not doubt but that every generation in posterity will be as much superior to us in political, and all kinds of knowledge, and that they will be able to improve upon the best civil and religious institutions that we can prescribe for them. ${ }^{14}$

The course of Lectures would show, he thought, that World History records developments and improvements. In particular, there has been progress in personal liberty, religious knowledge (by which he meant the growth of unitarian belief), and what he called personal security, that is advances in commerce, wealth and the conveniences of life, what we would call technology. The study and course of history demonstrates the vision and goodness of God. Catastrophes, misfortunes, setbacks and wars were not ignored in the Lectures. But a '[r]egard to Divine Providence $[. .$.$] throw [s] an agreeable light [even] upon the most gloomy and$ disgusting parts' of the story of the past. Another happy product of the study and knowledge of history was that it 'tends to free the mind from many foolish prejudices, particularly an unreasonable partiality for our own country.' By looking at World History and not just national history we can see the beneficent direction of history and get a full picture of the course of improvement. ${ }^{15}$

The idea of progress, which was increasingly current and discussed in mid-eighteenth-century Britain, had varying origins and expressions. In England, the other chief exponents were not primarily writers of history but, like Priestley, they drew their convictions about progress from their religious views. The most important English historian of the period, however, is associated with decline rather than progress and did not draw his ideas about the course of history from any religious convictions. Gibbon did accept that there was some evidence of progress in contemporary Britain, but he did not think that progress was inevitably or generally part of the course of history. The Scottish Enlightenment writers who discussed the matter on the whole took a more cyclical view 
of the course of history than Priestley and were more tentative than he when they talked about progress. ${ }^{16}$

From among the first rank of these writers, Lord Kames, David Hume, Adam Smith, and William Robertson, only Robertson agreed with Priestley in placing much emphasis on the role of God in shaping history. Smith's 'hidden hand' and doctrine of unintended consequences, for example, was 'a conception of general Providence [...] devoid of traditional Christian connotations.' Hume, of course, had no place for God in his reading of history. Robertson, a leader of the so-called Moderate party in the Church of Scotland, a one-time moderator of the general assembly of the Church, and a long-serving principal of Edinburgh University, did allow for a divine plan in some of his writings, but he underplayed the idea in his historical works. Neither Robertson nor the other British writers about progress of whatever ilk shared the 'brooding pessimism [...] that so often surfaced in Diderot, Montesquieu, and Voltaire'. On the other hand, they did not, like Priestley, espouse a single unifying causal system, or what has been called 'a comprehensive theology of history' to account for progress. They offered a number of explanations for progress: human nature, climate, social context, accident, division of labour, government and law, and so on. In the field of religion, if historians like Hume, Gibbon or Voltaire saw any progress at all, they viewed it as a thinly disguised secularization. For Priestley progress, which was clearly a demonstration of the active presence of the Divine Will, was present in the development, rather than the diminution, of religion. He shared their concern with the corrosive effects of priestcraft and superstition but was cheered by the evidence he saw of the growth of true rational religion. The study of history, therefore, was for him an act of devotion which teaches us about the benevolence of God's management of the universe. ${ }^{17}$

The full Lectures on History were not published until 1788 although an outline of them had appeared in 1765 . They are a work about how history should be taught and studied rather than a work of history in themselves. In the years following the introduction of Priestley's new courses at Warrington, there was a great expansion in the teaching of modern history along the lines of his courses and Lectures at the other Dissenting academies in England. Similar initiatives and understandings about history were already in place at Scottish universities, although Priestley makes no mention of them in the Lectures. In England, the Dissenting academies were too isolated from the mainstream of establishment society, and had too few students for their example alone to have had much impact directly on the educational practices of the universities. The ideas of the Scottish writers about history had an influence on their society which few intellectuals in England, especially marginalized Dis- 
senters such as Priestley, could match. ${ }^{18}$ This situation led Priestley to thank God that he was born a Dissenter and not, therefore, educated at Oxford or Cambridge for, as he wrote in his Letter to Pitt (1787), 'while your Universities resemble pools of stagnant water, secured by dams and mounds, and offensive to the neighbourhood, ours [the Dissenting academies] are like rivers which taking their natural course fertilize a whole country.' After the publication of the Lectures, however, they were recommended by John Symonds, the professor of modern history at Cambridge, and, apparently, by the 1790 s they were studied at a number of American colleges. ${ }^{19}$

In order to appreciate the full picture of providential improvement, Priestley insisted, we have to go beyond conventional historical sources and subjects. The Lectures recommend that a great deal of attention be paid to the history of agriculture, the domestic arts, manufactures and commerce in various states and at various times in order fully to discern the shape and course of events. They also emphasize the importance of material evidence for a correct understanding of history. In addition to traditional non-literary sources such as ancient coins, medals and inscriptions we must, Priestley pointed out, examine and understand exchequer rolls, public and private ledger books, letters, diaries, monetary, financial and exchange systems, systems of fortifications and city plans in order to appreciate social and economic advances. Priestley was also an early advocate of using unofficial popular sources such as ballads and works of fiction in order to understand and appreciate the force, shape and importance of public opinion. ${ }^{20}$ Perhaps the fact that Dissenters in England were more at the periphery of society, than at the core, compared to Scottish intellectuals, or even to Voltaire, helps to account for the greater interest in popular opinion.

Five of the Lectures were devoted to helping students understand systems of chronology. At Warrington, Priestley used terrestrial and celestial globes to illustrate the measuring and computing of time and dates. Time must be understood, he taught, as a continuum, not just a random passage of events, just as History is a process of orderly, determined, material and human improvement. Only by possessing a clear understanding of the movement of History over time can we appreciate the true and providential direction of the course of events. Through Time we will see the interdependency rather than the independence of events. 'We can form', he wrote,

but very confused notions of the intervals of time, of the rise and fall of empires, and of the successive establishment of states, without some such general comprehension, as we may call it, of the whole current of time, as may enable us to trace out distinctly the dependence of events to distribute them into such periods 
and divisions as shall lay the whole claim of past transactions in a just and orderly manner before us. ${ }^{21}$

Priestley's solution to this difficulty in understanding the relationship of events over the passage of time in history was his two time Charts: the Chart of Biography (1765), which was dedicated to Hugh, Lord Willoughby of Parham, the president of the trustees of Warrington Academy and the only Presbyterian peer in Parliament (who had helped to procure an Edinburgh LL.D. for Priestley), and the New Chart of History (1769), which was dedicated to Benjamin Franklin. Priestley wrote, in his Memoirs, many years later, that the Edinburgh degree was awarded in recognition of the Chart of Biography, but that was probably only one factor, albeit an important one, among others in gaining the degree as a reward for his educational accomplishments at Warrington. ${ }^{22}$ Each Chart was accompanied by an explanatory Description and a Catalogue or Index of names and events. ${ }^{23}$ The purpose of the charts, he explained, was as an adjunct to his lectures. They would make it possible for the imagination to conceive the course of History in all its parts, and to comprehend what was co-existent and what was successive. Time is an abstract idea

not the object of any of our senses, and no image can properly be made of it, yet because it has a relationship to quantity [...] it admits of a natural and easy representation in our minds by the idea of a measurable space, and particularly that of a line. ${ }^{24}$

The actual charts were both two feet by three feet and covered the same period: 1200 B.C. to Priestley's own day. The size of the type is too small for classroom use. Rather they were designed to be hung on the wall for private study to augment and help reinforce what was learned from lectures or reading by using the imagination and by association. Both charts went into several editions in London and Philadelphia, during and shortly after Priestley's life. The Chart of Biography contains about two thousand names. The Chart of History records events in one hundred and six countries, states or places. The dates, by decades, are indicated on the horizontal margins of both charts. On the Biography chart (see figure 1$)^{25}$ the entries are divided into six categories:

Statesman and Warriors;

Divines and Metaphysicians (which includes political philosophers);

Mathematicians and Physicians (which includes all kinds of scientists);

Poets and Artists;

Orators and Critics (which includes authors of prose fiction);

Historians and Antiquarians (which includes lawyers and legal writers). 
A SPECIMEN of a CHART of BIOGRAPHY.

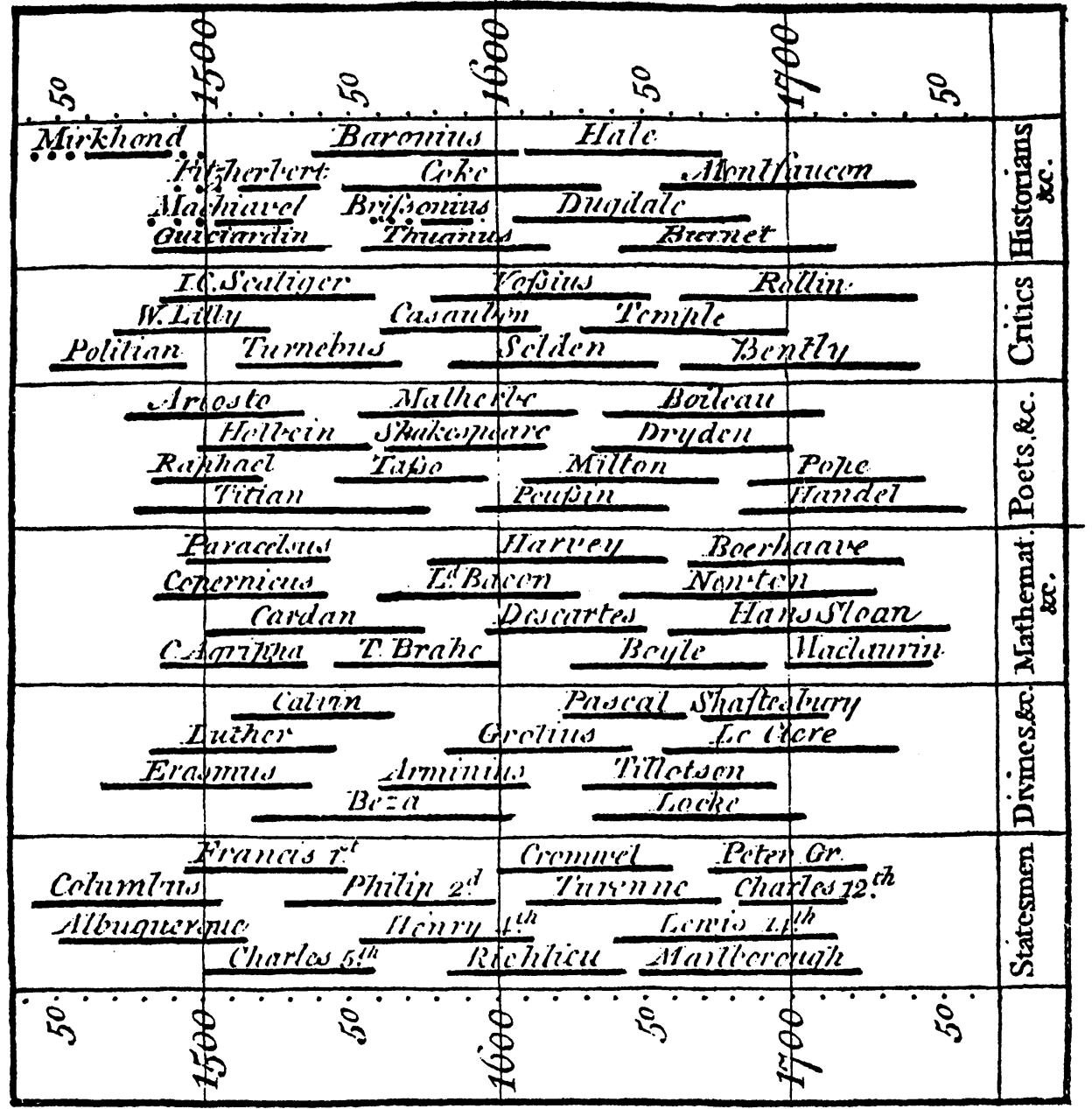

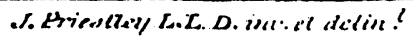

Figure 1

Priestley's principle of selection and inclusion was renown, rather than merit, so the Chart to some degree inevitably, he points out, reflects current opinions. A table based on Merit would have been very different from one based on Fame. But he wanted to be sure to include names of those whom his readers would have heard about. Hence, for example, under divines so many heretics of little merit are included because they are well-known. Here Priestley was being a little disingenuous. For he 
was obviously indulging his own preferences or sense of merit by including so many arians, socinians and other rational religious thinkers of little fame of whom he approved. ${ }^{26}$

There was also some difficulty about deciding in which category some individuals should be placed. He opted for what he thought was their most important activity. So, for example, Mohammed appears among Divines, but his successors in the Caliphate, among Statesman and Warriors. Writers with mixed characters presented the greatest difficulty. So Clarendon and Machiavelli appear among Historians, not Statesmen. But Cicero among Statesman, not Orators. Modern times were more of a problem for selection, because there are more known candidates. The Chart purposively excludes living persons since the issue of their renown has not been settled. Priestley acknowledges that Englishmen appear in disproportionately high numbers, but denies that this reflects partiality. Rather, this is a reflection of the principle of Fame, or perhaps familiarity, for selection. Priestley does attempt to be universal, and there are many non-Western names in all categories including under Divines where Jewish and, less frequently, Muslim figures appear. He apologizes for the under representation of Muslims, but again offers the explanation of familiarity, both to himself and to his readers. ${ }^{27}$

Statesmen are placed on the lower margin, where they are easier to see, because they are the names most familiar to readers. And, for reasons of ease and familiarity, and in order to demonstrate proximity and influence, he tries to keep people from neighbouring countries together on the Chart. Names from the Biblical, Persian, classical Greek, Hellenistic, Ptolemaic, Roman, and Byzantine worlds, and their successor nations in the modern world are included. But as one nation advances over another - the Romans over the Greeks, the English over the Scottish, France over the rest of Europe, Europeans over Asians - names from them achieve a more prominent place on the Chart. Familiarity justifies this arrangement, but also a sense of relative importance at any point in time.

The Chart of History is even more inclusive. Here, as in the Chart of Biography, Priestley can be seen to be applying the ideas which he had espoused in the Lectures about the importance of World History. Eighteenth-century historical writing was advocating a new cosmopolitanism. Voltaire, in his Essai sur les mœurs et l'esprit des nations [...] (1756) had gone beyond the borders of Europe as Robertson was to do in his History of America (1777) and An Historical Disquisition concerning [...] India (1791), but these works are not quite as inclusive as Priestley was trying to be. ${ }^{28}$

The vertical bands on the Chart (see figure 2) divide the whole Earth's surface into territories. ${ }^{29}$ They are, from bottom to top of the Chart: 


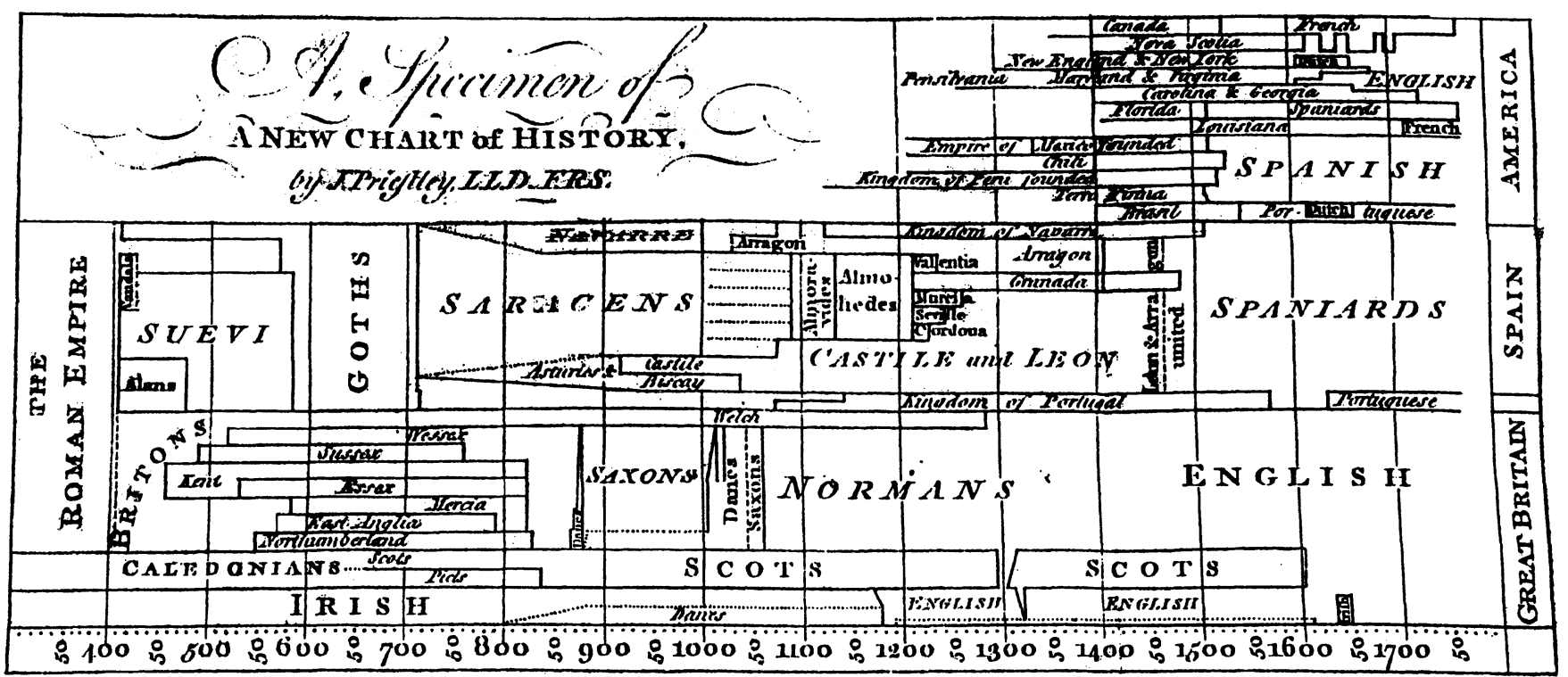

Figure 2 
The Northern Crowns (Scandinavia), Poland, Russia, Great Britain, Spain, France, Italy, Turkey in Europe, Germany, Turkey in Asia, Persia, India, China, Africa, America.

These are not strictly contiguous territories. And I have not been able to work out what the principle or system was in choosing this ordering. The History Chart, Priestley thought, is somewhat clearer to read than the biographical one. In any event, it involved fewer decisions to be made about who or what went where. It was more useful, he insisted, than an inferior chart which had lately been introduced from France. ${ }^{30}$

His New Chart of History, Priestley explained, was not a record of particular events, but rather of the duration of various empires, kingdoms and states, and of their relative importance at any time. He has been, he tells us, very precise in noting the changes of empire: ' $[t]$ hus, with respect to England, I have carefully marked the rise and progress of the Danes in this country, our conquests in Scotland and Ireland at different times, and the territories we once possessed in France. ${ }^{31}$ We can see the same thing in the Specimen of a New Chart of History (see figure 2): in Spain by following the progress and growth of the power of Castile, or in America, where, by Priestley's time, the Spanish and the English dominated. The Chart, then, and the accompanying Description, which contains a brief, usually half-page synopsis of the history of all the places on the Chart, reflect changes in power. The one hundred and six entries include not just the great states of the West in ancient and modern times. We also find, for example, the Italian city-states, the French provinces before national union, the principalities of India, Korea, China, Japan, Ethiopia, and all the overseas provinces of the European powers in Canada, Brazil, Peru, Mexico, and Louisiana. This gives us what the full title of the Description calls 'A View of the Principal Revolutions of Empire that have taken place in the World':

The capital use [of the Charts was as] a most excellent mechanical help to the knowledge of history, impressing the imagination indelibly with a just image of the rise, progress, extent, duration, and contemporary state of all the considerable empires that have ever existed in the world. If a person carry his eye horizontally, he sees, in a very short time, all the revolutions that have taken place in any particular country, and under whose power it is at present; and this is done with more exactness, and in much less time, than it could have been done by reading. I should not hesitate to say, that a more perfect knowledge of this kind of history may be gained by an hour's inspection of this chart, than could be acquired by the reading of several weeks. ${ }^{32}$ 
This is because the Charts are a way of 'seeing' or visualizing Time. They are sensible objects making a physical impression on the mind:

Time is continually suggested to us, by the view of [the Charts] under the idea of a river, flowing uniformly on, without beginning or end: [...] the lives of men $[\ldots]$ are little more than small straws swimming on the surface of this immense river. $^{33}$

The visible impression made by the Charts would do more than just help us to understand and recall the passage and duration of Time, and the succession of events. Priestley was influenced by, and helped to propagate, David Hartley's doctrine of association as a psychological and epistemological engine of great power. ${ }^{34}$ With the Charts he was innovatively applying these theories as pedagogical tools for the study of history. The Charts, he thought, would have the effect of fixing 'in the imagination, not in succession, but at once' the contemporary associations and relations of ideas and events at any point in Time. Thus the cross-cultural comparisons which Enlightenment history valued would be more easily, fully, and accurately comprehended. ${ }^{35}$

The actual physical arrangement of the Charts impressed the senses with an understanding that Time in History is not just passage or succession, but also co-existence. On both Charts the horizontal line conveys an idea of the duration of fame, influence, power and domination. A vertical reading conveys an impression of the contemporaneity of ideas, events and people. The number or density of entries, the 'thickness' in a sense, tells us about the vitality of any age. From the Chart of Biography, we learn about the extent and duration of great persons, the intervals, the successions, and, more importantly, the contemporary relations. We can associate the fame and importance of historical figures over periods of time. We can see and, therefore, understand which writers, artists, philosophers, and so on thrived at the same time, and under which rulers. ${ }^{36}$

The Chart of History is capable of an even more sophisticated reading. A horizontal reading yields the history of a particular country or area. Which power is dominant, over whom, and for how long. We obtain an impression of duration, or extent, over Time. On the other hand, we gain an appreciation of succession, change, or Revolution. If one of the spaces between one country and another is marked on the Chart by a full line it expresses conquest or forcible change of empire, Priestley explained, while a broken line signifies a peaceable revolution or transfer of dominion. A vertical reading gives 'the contemporary state of all the empires subsisting in the world at any particular time.' The varying width of the bands tells us about the magnitude or extent, at a point in Time, of a 
nation or people. The Chart shows us, at any particular period, who was rising and who was falling, and gives us a broader view of the relation of simultaneous events. This image of Time will lead us to apprehend that history, properly understood, is the history of the world, and not just of a nation. ${ }^{37}$

What did Priestley think that the Charts revealed about World History? He thought, as we have seen, that they would give a sense of proportion or relative importance and would free the student of history from national prejudices. Yet, despite his best intentions to be as universal as possible, European and especially English people and events, and progress towards what he thought of as rational religion, figure very largely. This is because the Charts, like the Lectures on History, are a story of human progress. The Charts confirmed, he thought, that true knowledge was accumulating with each succeeding generation. One could not just remain content with the wisdom of the ancient world. The pace of progress was accelerating, especially with regard to natural philosophy or science. There were, of course, void or thin spaces on the Charts. They were no less instructive than the broadest or thickest. They give us 'an idea of the great interruptions of science and the intervals at which it has flourished.' We can discern on the Charts a dark age in the medieval era with respect to philosophers, orators, and poets, that is with respect to the life of the imagination and science. 'But we see no void spaces in the column of Statesman, Heroes and Politicians. The world hath never wanted competitors for empire and power, and least in those periods in which the sciences and the arts have been most neglected.' Despite this gloomy note Priestley thought that it was a noble prospect to see on the Charts so much progress, over the last two centuries with respect to the arts, the comforts of life, commerce, manufactures and science. ${ }^{38}$

The Charts also had a religious purpose for Priestley which must not be overlooked. They demonstrated and confirmed the working out of Divine Providence. They remind us that God appoints or permits, that is, determines, all the changes or revolutions in the fame and fortunes of men and nations. Neither in the Charts nor in the Lectures did Priestley expound his belief in Providence to the point of the millennialism which was to figure in his later writings, especially after the beginning of the Revolution in France. ${ }^{39}$ He did contend, however, that God is always great and kind, and that the apparent evils in history are subservient to some divine benevolent purpose. Apparent disasters are, in fact, often favourable to the general progress of mankind. The study of history, as exhibited on the Charts, shows the benevolent conduct of Divine Providence. The divine will, and not human agency, is ultimately responsible for the course of improvement. Still, the example of God's benevolence 
will, in turn, inspire us to follow the true plain simple morality enjoined by a kindly God. ${ }^{40}$

Here Priestley was hinting at another use for the study of history. In the Lectures on History and in the Time Charts, he had argued that History was the proper preparation for a civil and active life in human society. It also, he contended, confirmed his notions about progress, determinism and divine benevolence. Increasingly, Priestley was to use history, and the reputation he had gained from the Lectures and the Charts, as part of his polemical defence of unitarianism against what the Rational Dissenters regarded as the course of deviant trinitarianism. The intention of unitarianism, and the purpose for which it used history, was not to overthrow Christianity but to reform it and restore it to its pristine state. If Christianity were examined historically, over time, we would discover a story of change, corruption, and eventual recovery. ${ }^{41}$ The study of history would vindicate the belief that simple unitarianism was the true and original Christian faith. Priestley's An History of the Corruptions of Christianity (1782), An History of the Early Opinions concerning Jesus Christ (1786), A General History of the Christian Church to the Fall of the Western Empire (1790), and A General History of the Christian Church from the Fall of the Western Empire to the Present Time (1802-03) were all part of this enterprise.

These works produced many replies from trinitarian Christians, both in the Church of England and from among orthodox Dissenters, and led to protracted polemical exchanges. For both Priestley and his opponents, history became embroiled in doctrinal controversy. Gibbon, perhaps fearing for the advancement of his career and genuinely convinced about the social utility of orthodox religion, did not want to be seen to be on the wrong side of this controversy. In an exchange of letters with Priestley in 1782 , he specifically dissociated his own views of the history of the development of Christian doctrine from the unitarian notions advanced by Priestley. Clearly Gibbon did not, like Priestley, see the study of history as a tool for rediscovering or promoting religious truth against the errors of established orthodoxy. Maintaining the theatre of superstition was a delicate but necessary business, he thought, and the socially responsible scholar had no business attacking any part of established religion simply on the grounds of intellectual soundness or personal religious conviction. ${ }^{42}$

The writing of history had a pugnacious and apologetic function in the theological disputes of the late eighteenth century. An attack on existing historical scholarship was part of the rhetorical armoury which was used in these disputes. The "claim to be an "historian" was to manufacture integrity and moral authority' for oneself. It was not only necessary to expose the tendentiousness of one's opponents. Estab- 
lishing the posture of an 'impartial, independent, and veracious historian was central to the ideological function' of the uses of history in this context. ${ }^{43}$ Priestley had gained this kind of historical reputation early in his career with his Charts and was now prepared to use it for the distinctly partisan purpose of undermining and discrediting the positions of his theological opponents.

\section{ARTHUR SHEPS \\ University of Toronto}

\section{Notes}

1 See H. McLachlan, Warrington Academy: Its History and Influence (Manchester: Manchester University Press, 1943) and P. O'Brien, Warrington Academy, 1757-86: Its Predecessors and Successors (Wigan: Owl Books, 1989). Works on the Dissenting academies in general include I. Parker, Dissenting Academies in England: Their Rise and Progress, and their Place among the Educational Systems of the Country (Cambridge: Cambridge University Press, 1914); H. McLachlan, English Education under the Test Acts, Being a History of the Nonconformist Academies, 1662-1820 (Manchester: Manchester University Press, 1931); and J.W. Ashley Smith, The Birth of Modern Education: The Contribution of the Dissenting Academies, 1600-1800 (London: Independent Press, 1954). There is also some discussion of the academies in Michael R. Watts, The Dissenters. From the Reformation to the French Revolution, vol. 1 (Oxford: Clarendon Press, 1978) 367-71.

2 See David L. Wykes, 'The contribution of the Dissenting academy to the emergence of Rational Dissent', Enlightenment and Religion, Rational Dissent in eighteenth-century Britain by Knud Haakonssen (Cambridge: Cambridge University Press, 1996) 132-36.

3 Joseph Priestley, Memoirs of Dr. Joseph Priestley, to the Year 1795, written by himself: with a continuation, to the time of his decease, by his son, Joseph Priestley ... (London, 1806) 45, 59-65; and Priestley, An Essay on a Course of Liberal Education for Civil and Active Life, with Plans of Lectures on the Study of History and General Policy, on the History of England, and on the Constitution and Laws of England (London, 1765), The Theological and Miscellaneous Works of Joseph Priestley, LL.D. F.R.S. Ec., ed. J.T. Rutt, 25 vols., XXIV, 11, 1817-32 (New York: Krauss Reprint Company, 1972) 440-463. The outlines of the lectures were also published separately as The Syllabus of Lectures on History and General Policy (Warrington, 1765).

4 See Parker, Dissenting Academies 74-75; and Watts, Dissenters 37-71. For the English universities, The University of Oxford. The Eighteenth Century, ed. L.S. Sutherland and L.G. Mitchell, vol. 5 (Oxford: Clarendon Press, 1986); and John Gascoigne, Cambridge in the Age of Enlightenment: Science, Religion and Politics from the Restoration to the French Revolution (Cambridge: Cambridge University Press, 1989) still remain the best works.

5 Essay on ... Education, Works, XXIV, 8-12. 
6 Essay ... on Education, Works, XXIV, 12-14, 17.

7 Essay ... on Education, Works, XXIV, 23; and his Lectures on History and General Policy ... (Birmingham, 1788), Works, XXIV, 34.

8 Lectures on History, Works, XXIV, 44-47. Isaac Kramnick, 'Eighteenth-Century Science and Radical Social Theory: The Case of Joseph Priestley's Scientific Liberalism', Journal of British Studies 25 (1986) 1-30; and his 'Religion and Radicalism; English Political Theory in the Age of Revolution', Political Theory 5 (1977) 505-34 usefully analyses Priestley's radical liberalism and attachment to the cause of progress and improvement. While acknowledging a providential element in Priestley's thought he sees Priestley's notions of improvement as part of a process of secularization. The importance, for Priestley, of the study of history as a religious act or as an aid to devotion and to an understanding of the will of Providence, is not considered here. In Alan Tapper, 'Priestley on politics, progress and moral theology', Haakonssen, Enlightenment and Religion, chapter 11, 272-86 Priestley's religious ideas and attachments are considered in connection with his writings on political and moral theory. A sophisticated and thorough attempt to reconcile Priestley's scientific work with his religion can be found in the various articles by John G. McEvoy which are referred to in his 'Causes and Laws, Powers and Principles: The Metaphysical Foundations of Priestley's Concept of Phlogiston', Science, Medicine and Dissent: Joseph Priestley (1733-1804), ed. R.G.W. Anderson and Christopher Lawrence (London: Wellcome Trust, 1987) 55-72, especially, 'Enlightenment and Dissent in Science: Joseph Priestley and the Limits of Theoretical Reasoning', Enlightenment and Dissent 2 (1983) 47-67; 'Electricity, Knowledge, and the Nature of Progress in Priestley's Thought', British Journal for the History of Science 12 (1979) 1-30, and with J.E. McGuire; 'God and Nature: Priestley's Way of Rational Dissent', Historical Studies in the Physical Sciences 6 (1975) 325- 404.

9 Priestley, Memoirs 19.

10 Priestley composed a treatise on divine influence sometime in the late 1750s at Needham Market which was eventually incorporated into a published ordination sermon, The Doctrine of Divine Influence on the Human Mind (Bath, 1779); see Memoirs 35.

11 Priestley, Essay on First Principles of Government (London, 1768), Works, XXII, 6. See also the 'Preface' to his An Examination of Dr. Reid's inquiry into the Human Mind ... (London, 1774) Works, III, 4-14.

12 Memoirs, 79-81.

13 Lectures on History, Works, XXIV, 44-47.

14 Essay on ... Government, Works, XXII, 141.

15 Lectures on History, Works, XXIV, 32, 47, 421-25.

16 Karen O'Brien, Narratives of Enlightenment, Cosmopolitan History from Voltaire to Gibbon (Cambridge: Cambridge University Press, 1997) 202-03. The process of improvement, she notes, was 'a faltering, contingent, and uncertain business' for Gibbon and Hume.

17 See David Spadafora, The Idea of Progress in Eighteenth-Century Britain (New Haven: Yale University Press, 1990) especially 222-52, 261, 273-75, 286-87, 301, $309-10,316,374-77,385$ (the quotations are from 310, 316, 385), for an exhaustive analysis of the currency and various expressions of these notions. See $\mathrm{O}^{\prime} B$ Bien, 
Narratives 125-26 and Nicholas Phillipson, 'Providence and progress: an introduction to the historical thought of William Robertson', William Robertson and the Expansion of Empire, ed. Stewart J. Brown (Cambridge: Cambridge University Press, 1997) 74-91 for how Robertson tried to reconcile his Calvinism with Enlightenment thought about human agency. The terse discussion about Priestley's ideas of historical progress in Robert E. Schofield, The Enlightenment of Joseph Priestley, A study of His Life and Work from 1733 to 1773 (University Park, Penn.: Pennsylvania State University Press, 1997) 125 emphasizes the mechanistic rather than the providential.

18 David Allan, Virtue, Learning, and the Scottish Enlightenment (Edinburgh: Edinburgh University Press, 1993) 109-43, 207-18; Richard B. Sher, Church and University in the Scottish Enlightenment (Edinburgh: Edinburgh University Press, 1985) 93-119; Wykes, 'The Dissenting Academy ...' ', Enlightenment and Religion 133; Spadafora, Idea of Progress 261.

19 Priestley, Familiar Letters addressed to the Inhabitants of Northumberland (Birmingham, 1790), Works, XIX, 214 ; and his A Letter to the Right Hon. William Pitt .... on the Subjects of Toleration and Church Establishments ..., Works, XIX, 128; Anthony Lincoln, Some Political and Social Ideas of English Dissent, 1763-1800 (Cambridge: Cambridge University Press, 1938) 72, 84-89, 98-100; Kramnick, 'Eighteenth-Century Science and ... Priestley's Scientific Liberalism', Journal of British Studies 25 (1986) 1-30.

20 See, in particular, lectures 19, 31, 37, 50,51, 52, 54, 64, and 65 in Lectures on History, Works, XXIV, 137, 191-96, 217-20, 300-316, 333-38, 405-15. John Mclachlan, 'Joseph Priestley and the Study of History', Transactions of the Unitarian Historical Society, XIX (1990), 252-63, contends that Priestley was a forerunner of social and economic history. It would be more precise to say that he was innovative in his advocating the use of a wide range of evidence, including unofficial sources of popular opinion. Voltaire had looked at court life, religious quarrels, and artistic, social and economic achievements but not at genuinely popular culture. For both Voltaire and Hume public opinion was essentially passive. Robertson ascribed more force to it, but it was elite opinion that he looked at and he did not suggest that it had a structuring role. See Karen O'Brien, 'Robertson's place in the development of eighteenth-century narrative history', Brown, William Robertson 79-80, 82-83.

21 Lectures on History, Works, XXIV, 101-02.

22 The degree was awarded on December 4, 1764, and the Chart was not published until February 2, 1765. So either Priestley's recollection that the degree was awarded for the Chart is faulty and the degree was in fact awarded for other services to education, or the degree was awarded at least partly on the basis of the reputation of the Chart in advance of its actual publication. The latter is a possibility since, according to his Memoirs (49), he had begun work on it while teaching school at Nantwich, in Cheshire, from 1758 to 1761 . That is, like the Lectures on History, a version of which was in use at Warrington in the 1760s, although they were not published in their finished form until 1788, a version of the Chart may have been in use and known about before its registered date of publication. Priestley's account in his Memoirs (52) was that Thomas Percival, then a medical student at Edinburgh, procured the degree for him after the publication of the Chart of Biography. Schofield, Priestley 118-19, 130-31, points out that, in fact, Willoughby and a fellow trustee recommended Priestley to Edinburgh, and had the recommendation endorsed and forwarded by Percival, the son of another 
trustee, before the appearance of the Chart, as a reward for a number of his already published educational endeavours. Yet, as Schofield also notes (130), the 'forthcoming chart was a manifest element in winning, for Priestley, his cherished LL.D. from Edinburgh.' Schofield's discussion of the Charts (129-30, 132-34) is confined to useful comments on the sources for the chronology and a cursory description of the contents.

23 A Chart of Biography (London, 1765), and A New Chart of History (London, 1769). A Description of a Chart of Biography, with a Catalogue of all the Names inserted in it, and the Dates annexed to them (Warrington, 1765), Works, XXIV, 463-76; and A Description of a New Chart of History, containing a View of the Principal Revolutions of Empires that have taken place in the World (London, 1770), Works, XXIV, 477-515 were separately published, but meant to be sold along with the Charts.

24 Description of a Chart of Biography, Works, XXIV, 465; see also 'Lecture 18' of his Lectures on History, Works, XXIV, 133-36.

25 Figure 1 is a section taken from A Short Account of Dr. Priestley's Chart of Biography (London, 1770), which was a promotional broadsheet.

26 Description of a Chart of Biography, Works, XXIV, 470-71.

27 Description of a Chart of Biography, Works, XXIV, 473-75.

28 O'Brien points out that, until Voltaire (who included the East but very little on Africa), eighteenth-century 'universal' history did not, except for the story of conquests, go much beyond the confines of Europe. Robertson's were the first major works in English to do so. In these new cosmopolitan histories other civilizations were allowed to develop independently of Europe, but the focus and the narrative line were still European. O'Brien, Narratives, 2-12, 21, 47-51; and her 'Robertson's place in the development of eighteenth-century narrative history', Brown, William Robertson 74-91.

29 Figure 2 is a section of $A$ Specimen of a New Chart of History (London, 1770), which was a promotional broadsheet.

30 Priestley, A Description of a New Chart of History, containing a View of the Principal Revolutions of Empires that have taken place in the World (London, 1770), Works, XXIV, 477; and his Lectures on History, Works, XXIV, 133. The Description was published one year after the New Chart of History itself. The other chart referred to is probably A Chart of Universal History (Done from the French with considerable improvements.) (London, 1750).

31 Description of a New Chart of History, Works, XXIV, 478.

32 Description of a New Chart of History, Works, XXIV, 479-80.

33 Description of a Chart of Biography, Works, XXIV, 476.

34 See Priestley, Hartley's Theory of the Human Mind on the Principle of the Association of Ideas, with Essays relating to the subject of it (London, 1775), which was a reprinting of parts of Hartley's Observations on Man (1749), with Priestley's own commentary.

35 Description of a Chart of Biography, Works, XXIV, 466.

36 Description of a Chart of Biography, Works, XXIV, 465-68.

37 Description of a Chart of History, Works, XXIV, 479-81.

38 Description of a Chart of Biography, Works, XXIV, 475-76. 
39 For Priestley's millennialism see Clarke Garrett, 'Joseph Priestley, the Millennium, and the French Revolution', Journal of the History of Ideas 34 (1973) 51-66; Jack Fruchtman, Jr., The Apocalyptic Politics of Richard Price and Joseph Priestley: A Study in Late Eighteenth-Century English Republican Millennialism. Transactions of the American Philosophical Society, 73, 4 (Philadelphia: American Philosophical Society, 1983); Martin Fitzpatrick, 'Joseph Priestley and the Millennium', Science, Medicine and Dissent: Joseph Priestley (1733-1804), ed. Anderson and Lawrence, 29-38; and Robert M. Ryan, The Romantic Reformation: Religious Politics in English Literature, 1789-1824 (Cambridge: Cambridge University Press, 1997) 209-10. See also Clarke Garrett, Respectable Folly: Millenarians and the French Revolution in France and England (Baltimore: Johns Hopkins University Press, 1975), and Martin Fitzpatrick, 'The Enlightenment, politics and providence: some Scottish and English comparisons', Haakonssen (ed.), Enlightenment and Religion 64-98.

40 Description of a New Chart of History, Works, XXIV, 483-84. Fruchtman, Apocalyptic Politics of ... Priestley, tries to graft Priestley's providentialism and millennialism to some degree of human agency and civic responsibility for creating the conditions for improvement. Insofar as proper human behaviour was, for Priestley, dictated by sublunary political considerations they were subject to the influence of Locke's ideas. See Isaac Kramnick, 'Republican Revisionism Revisited', American Historical Review 86 (1982) 629-64, and his 'Eighteenth-Century Science and ... Priestley's Scientific Liberalism', Journal of British Studies 25 (1986) 1-30; Spadafora, The Idea of Progress 431, 445.

41 See J.A.I. Champion, The Pillars of Priestcraft Shaken, The Church of England and its Enemies, 1660-1730 (Cambridge: Cambridge University Press, 1992) especially chapter 4, 'Historia Monotheistica', for a suggestive and useful discussion of the use of history in early modern theological disputes. Champion also points out how important it was for unitarian polemics to portray Islam and Judaism as serious monotheistic faiths and not merely as heresies or failures to absorb the Christian message. Priestley's A Comparison of the Institutions of Moses with those of the Hindoos and other ancient Nations, with Remarks on M. Dupuis's Origin of all Religions; ... the Laws and Institutions of Moses methodized: and an Address to the Jews on the present State of the World, and the Prophecies relating to it (Northumberland, 1797 ) is an instance of this kind of use of history.

42 The Priestley-Gibbon letters are to be found in Works, XVII, 533-36. Gibbon opposed publication of the letters at the time because he feared that any association with Priestley would hurt his prospects of patronage and advancement. But Priestley, as he told Theophilus Lindsey, another leading rational dissenter, prefixed the letters to his Discourses on the Evidence of Revealed Religion (London, 1794), after Gibbon's death since he thought that by then there was no breach of honour (Lindsey to W. Turner, London, March 24, 1794, in Doctor Williams' Library, London, Mss. Mod. 12.44, f. 57). See Paul Turnbull, 'Gibbon's Exchange with Joseph Priestley', British Journal for Eighteenth-Century Studies 14 (1991) 139-58.

43 Champion, Priestcraft 39, 46. 